Mr. V. Jayasekeran, of the Haematology Laboratory, Thomson Road General Hospital, Singapore, for carrying out most of the routine haematological investigations on our patients.

\section{REFERENCES}

Baker, S. J., Ignatius, M., Johnson, S., and Vaish, S. K. (1963). Brit. med. $\mathcal{J}_{\text {., }} 1,1713$.

Chhuttani, P. N. (1948). Indian med. Gaz., 83, 508

Crosby, W. H., and Kugler, H. W. (1957). Amer. F. dig. Dis., 2, 236.

Das Gupta, C. R., and Chatterjea, J. B. (1951). Blood, 6, 631

Friedlander, R. D. (1934). Amer. F. med. Sci., 187, 634.

Glass, G. B. J., Boyd, L. J., Gellin, G. A., and Stephanson, L. (1954). Arch. Biochem., 51, 251.
Kay, A. W. (1953). Brit. med. 7., 2, 77.

Konar, N. R. (1951). Indian med. Gaz., 86, 237.

Misra, S. S., and Singh, B. N. (1961). 7. Indian med. Ass., 36, 105. Mollin, D. L., Booth, C. C., and Baker, S. J. (1957). Brit. F. Haemat., 3,412 .

and Ross, G. I. M. (1957). Vitamin $B_{12}$ and Intrinsic Factor, edited

by H. C. Heinrich, p. 413 . Stuttgart.
Morris, H. H. (1929). China med. $7 ., 43,768$.

Osler, William (1916). The Principles and Practice of Medicine, 8th ed. p. 736. London.

Schilling, R. F. (1953). f. Lab. clin. Med., 42, 860.

Schwartz, S. O., and Rappolt, L. A. (1945). Arch. intern. Med., 75, 404

Taylor, G. F., and Chitkara, N. L. (1940). Indian med. Gaz., 75, 16

Waters, A. H., and Mollin, D. L. (1961). F. clin. Path., 14, 335.

Yang, C. S., and Keefer, C. S. (1931). Nat. med. 7. China, 17, 218.

\title{
Effects of Rabies Vaccine in Man
}

\author{
J. C. M. SHARP,* M.B., CH.B., D.P.H. ; SHEILA MCDONALD, $\dagger$ M.D.
}

Brit. med. F., 1967, 3, 20-21

Few opportunities are available in the United Kingdom to study the effects of rabies vaccine in man. Immunization is restricted to those exposed to a definite risk of infection as the course is prolonged, is painful, and may be associated with complications such as peripheral neuritis, dorsolumbar myelitis, and acute ascending Landry type myelitis; major paralytic incidents develop in about 1 in 6,000 persons given treatment (Parish and Cannon, 1962).

In 1965 an opportunity arose in Edinburgh to study the effects of the Semple vaccine, a killed virus suspension of rabbit origin, which was used to immunize 20 persons who had been exposed to infection from a rabid leopard cub.

\section{Epidemiological History}

On 30 October 1965 a 3-month-old leopard arrived at Edinburgh Zoo by air from Nepal. On arrival the animal was emaciated and attempts to force-feed it failed. The animal's condition deteriorated and four days later it was transferred to the Royal (Dick) Veterinary College in Edinburgh, where it died the next day. Encephalitis was found at post-mortem examination and inclusion bodies in the brain tissue suggested the diagnosis of rabies. The animal's head was sent to the Central Veterinary Laboratory, Weybridge, Surrey, for further examination.

At the zoo it was found that four adults (A, B, C, and D) and three children (E, F, and $G$ ) had received bites, scratches, and licks from the leopard (Table I). Three adults (A, B, and $C)$ and one child (E) who had been bitten on their hands were given a single dose of antiserum and with the others were started on a 14-day course of Semple vaccine before rabies was confirmed. One week later a further five persons $(H, I, J$,

- Senior Medical Officer, Health and Social Services Department, Edinburgh.

t Lecturer in Bacteriology, University of Edinburgh.
$\mathrm{K}$, and L) admitted contact with the leopard and were also given vaccine. Four were employees of British European Airways at Edinburgh Airport, who had allowed the animal to lick their abraded hands. The fifth (L) had fed the animal at the zoo but had later left for other employment.

On 2 December the laboratory at Weybridge confirmed the diagnosis of rabies after mice inoculation tests. It was then decided to vaccinate eight other persons who had been at some risk. Four (M, N, O, and P) were zoo employees who had not previously admitted their contact with the animal. The others were a kennel maid (Q) and three veterinary surgeons (R, S, and T) at the Royal (Dick) Veterinary College, who had had their scratched hands in the animal's mouth. The four contacts (A, B, C, and E) most seriously at risk and one other (D) were given further treatment. Four (A, B, D, and E) were given six additional doses of vaccine, but $C$, who became unwell, received only four doses. The first four doses were given daily, beginning one week after completion of the original 14-day course; the remaining two booster doses were given to $\mathrm{A}, \mathrm{B}, \mathrm{D}$, and $\mathrm{E}$ at 10 -day intervals.

Three other persons had been in contact with the animal, but as they had not been bitten, scratched, or licked, no vaccine was given. In all, 20 persons were vaccinated $(12$ males and 8 females). Their ages ranged from 8 to 59 .

\section{The Vaccine and its Administration}

The vaccine, obtained from the Lister Institute of Preventive Medicine, Elstree, Herts, was a sterile preparation of killed rabies virus in $0.5 \%$ phenolized saline containing a $4 \%$ suspension of the brains of rabbits that had died after inoculation with " fixed" rabies virus. Graded doses were given, varying from 2 to $4 \mathrm{ml}$. for the adults and from 1.5 to $2.5 \mathrm{ml}$. for the children. The daily injections were made subcutaneously into alternate sides of the anterior or lateral abdominal wall. All

TABle I.-Prophylactic Treatment Given to Persons At Risk in Relation to the Extent of their Exposure to Infection

\begin{tabular}{|c|c|c|c|c|c|c|c|c|c|c|c|c|c|c|c|c|c|c|c|c|}
\hline \multirow[b]{2}{*}{ Contact: } & \multicolumn{7}{|c|}{ Group at Greater Risk } & \multicolumn{13}{|c|}{ Group at Lesser Risk } \\
\hline & $\mathbf{A}$ & B & C & $\mathbf{D}$ & $\mathbf{E}$ & $\mathbf{F}$ & $\mathbf{G}$ & $\mathbf{H}$ & $\mathbf{I}$ & $\mathbf{J}$ & $\mathrm{K}$ & $\mathbf{L}$ & $M$ & $\mathrm{~N}$ & 0 & $\mathbf{P}$ & Q & $\mathbf{R}$ & $\mathbf{s}$ & $T$ \\
\hline $\begin{array}{l}\text { Degree of exposure to } \\
\text { infection . } \\
\text { Antiserum given } \\
\text { Volume of vaccine } \\
\text { given (ml.) }\end{array}$ & $\begin{array}{c}\text { BL } \\
+ \\
66\end{array}$ & $\begin{array}{c}\text { BL } \\
+ \\
66\end{array}$ & $\begin{array}{c}\text { B } \\
+ \\
58\end{array}$ & $\frac{S}{66}$ & $\begin{array}{l}\text { B } \\
+ \\
42\end{array}$ & $\begin{array}{l}\text { SL } \\
29\end{array}$ & $\begin{array}{l}\text { SL } \\
29\end{array}$ & L & $\underline{\mathbf{L}}$ & $\underline{L}$ & $\underline{L}$ & $\underline{s}$ & $\stackrel{\text { S }}{1 \text { rece }}$ & $\underline{\mathrm{L}}$ & $\underline{L}$ & $\underline{L}$ & $\stackrel{\mathrm{H}}{-}$ & $\stackrel{\mathbf{H}}{-}$ & $\stackrel{\mathrm{H}}{-}$ & $\underline{\mathbf{H}}$ \\
\hline
\end{tabular}


vaccinated were encouraged to lead a normal life but warned to avoid excessive fatigue and alcohol during vaccination (Parish and Cannon, 1962) and for 10 days after the course.

\section{Reactions}

Six persons had their vaccine course interrupted because they felt unwell. Thirteen reported symptoms by the fourth day. A further three complained by the end of the first week and the remaining four reported symptoms by the 13th day (Table II). The earliest symptoms were increasing physical lethargy (17 cases), sleepiness during the day (16), and difficulty in (aged 15) were not seriously affected despite continuing normal physical activities. It may be that susceptibility to vaccine reactions increases with age. The two persons most seriously affected were aged $59(\mathrm{C})$ and $40(\mathrm{H})$.

Some of the symptoms described above may have been psychological in origin, but this report does show that a high incidence of reactions can follow immunization with the Semple vaccine. Passive immunization with rabies antiserum may give better protection than active immunization, but to be of value it must be administered within 72 hours of exposure. Until more conclusive evidence is available, active immunization will continue to be part of post-exposure treatment (Hildreth, 1963). Attempts to develop vaccines less hazardous

TABLE II.-Day of Onset and Severity of Reactions in Relation to Age of Contacts

\begin{tabular}{|c|c|c|c|c|c|c|c|c|c|c|c|c|c|c|c|c|c|c|c|c|}
\hline \multirow[b]{2}{*}{ Contact: } & \multicolumn{7}{|c|}{ Group at Greater Risk } & \multicolumn{13}{|c|}{ Group at Lesser Risk } \\
\hline & A & B & C & D & $\mathbf{E}$ & $\mathbf{F}$ & $\mathbf{G}$ & $\mathbf{H}$ & I & $\mathbf{J}$ & $\mathbf{K}$ & L & $\mathbf{M}$ & $\mathbf{N}$ & $\mathbf{O}$ & $\mathbf{P}$ & $\mathbf{Q}$ & $\mathbf{R}$ & $\mathbf{S}$ & $\mathbf{T}$ \\
\hline $\begin{array}{l}\text { Age in years } \\
\text { Day of onset of reac- } \\
\text { tion after start of } \\
\text { vaccine course } \ldots \\
\text { Severity of reactions }\end{array}$ & $\begin{array}{l}41 \\
\text { 2nd } \\
++\end{array}$ & $\begin{array}{l}25 \\
2 n d \\
++\end{array}$ & $\begin{array}{c}59 \\
8 \text { th } \\
+++\end{array}$ & $\begin{array}{l}22 \\
6 \text { th } \\
++\end{array}$ & $\begin{array}{r}8 \\
4 \text { th } \\
++\end{array}$ & $\begin{array}{l}11 \\
+ \text { th } \\
+\end{array}$ & $\begin{array}{l}11 \\
4 \text { th } \\
+\end{array}$ & $\begin{array}{c}40 \\
4 \text { th } \\
+++\end{array}$ & $\begin{array}{l}34 \\
3 \text { rd } \\
++\end{array}$ & $\begin{array}{c}32 \\
3 \mathrm{rd} \\
+\end{array}$ & $\begin{array}{l}25 \\
3 \mathrm{rd} \\
+\end{array}$ & $\begin{array}{c}35 \\
10 \text { th } \\
+\end{array}$ & $\begin{array}{l}15 \\
7 \text { th } \\
++\end{array}$ & $\begin{array}{l}27 \\
3 \text { rd } \\
++\end{array}$ & $\begin{array}{l}27 \\
\text { 2nd } \\
++\end{array}$ & $\begin{array}{l}22 \\
7 \text { th } \\
+\end{array}$ & $\begin{array}{c}35 \\
3 \mathrm{rd} \\
+\end{array}$ & $\begin{array}{l}23 \\
3 \mathrm{rd} \\
++\end{array}$ & $\begin{array}{c}44 \\
10 \text { th } \\
++\end{array}$ & $\begin{array}{l}42 \\
13 \text { th } \\
+\end{array}$ \\
\hline
\end{tabular}

wakening in the morning (10). Only $\mathrm{L}$ and $\mathrm{T}$ had no such complaints.

Nineteen persons complained of erythema, induration, and tenderness around the injection sites. Pruritus was reported by 15 persons, including $\mathrm{J}$, who had no other local symptoms. Axillary lymphadenopathy was observed in seven persons, two of whom ( $\mathrm{R}$ and $\mathrm{H}$ ) also developed inguinal adenitis.

Mental symptoms such as impaired concentration (14 cases) and forgetfulness (11) also occurred during the first week. Six persons reported episodes of confusion of thought, three of whom also experienced amnesia. Difficulty in getting off to sleep or nightmares were reported by six persons, one of whom had frequent nocturnal emissions.

Headaches of varying severity and frequency were experienced by 13 persons. Three persons, including two of the children, had difficulty with visual focusing. Single fainting attacks were reported by two persons during the first week. Episodes of acute nervous tension and frontal headache were experienced by $\mathrm{C}$ after the 18th injection. These symptoms, which recurred with diminishing frequency for six weeks, resulted in his being confined to bed at home.

Neurological symptoms developed in six persons. The most seriously affected was $\mathrm{H}$, who developed acute left-sided motor and sensory disturbances, including paresis of the deltoid, triceps, and hemidiaphragm on the seventh day. This resulted in his admission to hospital, where his vaccine course was completed under corticosteroid cover. Temporary paraesthesia of the extremities was reported by $I$ and $T$. $H$ and $I$ also complained of intention tremor when writing. Intermittent weakness of the quadriceps was reported by $\mathrm{N}$, while $\mathrm{R}$ experienced frequent twitching in unrelated muscle groups.

Less common experiences were dryness of the mouth with marked thirst (A, B, and D), anorexia (B), frequency of micturition (A), difficulty in maintaining urinary flow $(\mathrm{H})$, diarrhoea (D and $\mathrm{O}$ ), low backache (D and $\mathrm{N}$ ), and alopecia (C).

\section{Discussion}

Though many of the reactions experienced by the 20 vaccinated persons were minimal, some of which were reported in retrospect only, two persons ( $\mathrm{C}$ and $\mathrm{H}$ ) were seriously ill and absent from work for two and three months respectively. Others suffered seyere discomfort.

Several persons aggravated their symptoms by failing to restrict physical exertion. However, the three children and $M$ than the Semple preparation have not been entirely successful. The duck embryo vaccine was thought to be devoid of the tissue component responsible for neurological complications, but this has not been substantiated. The high-egg-passage Flury vaccine which is used for pre-exposure immunization is not recommended for post-exposure treatment (Horsfall and Tamm, 1965). Post-infection treatment of guinea-pigs has also shown that the protection given by the duck embryo or the high-egg-passage Flury vaccine is less than that given by the Semple vaccine (Veeraraghavan and Subrahmanyan, 1963).

Though quarantine arrangements are approved by the Department of Agriculture and Fisheries in Scotland, only verbal instructions are given to zoos regarding precautions to be taken with imported animals. Written instructions, however, are issued to all other registered quarantine stations. In view of the incident reported here, it is strongly recommended that similar written instructions be given to and be implemented at zoos. This report emphasizes the importance of restricting human access to animals in quarantine, thus minimizing the number of persons exposed to possible infection and subsequently to the hazards of immunization.

\section{Summary}

An outline is given of the reactions experienced by 20 persons who were immunized with Semple rabbit-brain vaccine after exposure to infection from a rabid leopard cub. Two persons were seriously ill and others suffered severe discomfort. The importance of restricting human access to animals in quarantine in order to reduce the number of persons requiring vaccination is emphasized.

We wish to thank Dr. J. L. Gilloran, Medical Officer of Health, City of Edinburgh, for permission to publish this paper; also Dr. A. Jamieson, Mr. J. Norval, veterinary inspector, and the Tropical Diseases and Infectious Diseases Unit of the Edinburgh City Hospital for their valuable assistance.

\section{REFERENCES}

Hildreth, E. H. (1963). Ann. intern. Med., 58, 883.

Horsfall, F. L., and Tamm, I. (1965). Viral and Rickettsial Infections of Man, 4th ed., p. 828. London.

Parish, H. J., and Cannon, D. A. (1962). Antisera, Toxoids, Vaccines and Tuberculins in Prophylaxis and Treatment, 6th ed., p. 221. Edinburgh.

Veeraraghavan, N., and Subrahmanyan, T. P. (1963). Bull. Wld Hlth Org., 29, 323. 